\title{
COMPARISON BETWEEN TWO METHODS OF DENTALAGE ESTIMATION AMONG EGYPTIAN CHILDREN
}

\author{
$B \mathcal{Y}$ \\ Amal A. El-Bakary, Shaza M. Hammad * and Fatma M. Ibrahim ** \\ Departments of Forensic Medicine and Clinical Toxicology, Faculty of Medicine, *Orthodontics, \\ **Oral-histology, Faculty of Dentistry, Mansoura University,
}

\begin{abstract}
The need to estimate the age of living individuals is becoming increasingly more important in both forensic science and clinical dentistry. The study of the morphological parameters of teeth on dental X-rays of adult humans is more reliable than are most other methods for age estimation. Willems and Cameriere methods are newly presented methods. The aim of this work was to evaluate the applicability of using these methods for Egyptian children. Digitalized panoramas taken from 286 Egyptian children (134 boys, 152 girls) with age range from 5 to 16 years were analyzed. The seven left permanent mandibular teeth were valued using the two methods. The results of this research showed that dental age estimated by both methods was significantly correlated to real age. However, Willems method was slightly more accurate (98.62\%) compared to Cameriere method (98.02\%). Therefore, both methods can be recommended for practical application in clinical dentistry and forensic procedures on the Egyptian population.
\end{abstract}

Key words: Dental age, Cameriere method, Willems method, Children, Forensic odontology.

\section{INTRODUCTION}

Age estimation in children is a fundamental question in forensic medicine, pediatric endocrinology and in orthodontic treatment. The need to evaluate age to consider legal responsibility, or for application of different laws for young people, requires reliable methods. The study of the morphological parameters of teeth and hand / wrist X-rays of children is more reliable than most other methods for age estimation and is most commonly used to determine age in living humans (Cameriere and Ferrante, 2008).

Tooth formation is widely used to assess maturity and to predict age. Within clinical dentistry, such information aids in diagnosis and treatment planning (Tunc and Koyuturk, 2008). The age range from 9 to 14 years remains the most critical with regard to estimating a child's dental age and consequently, to determine the proper timing for initiating orthodontic therapy (AlEmran, 2008). 
It is commonly accepted that tooth eruption as an evaluation method for dental age estimation has some limitations, since tooth eruption is heavily influenced by environmental factors such as available space in the dental arch, extraction of deciduous predecessors, tipping or impaction of teeth. Oppositely, the method for dental age estimation using developmental stages of teeth is more useful since tooth development is less influenced by environmental factors (Willems et al., 2001).

Numerous odontological studies have also been carried out to establish age, assessing mineralization within acceptable error limits. The most common method for dental age assessment was first published by Demirjian et al. (1973) and since then odontology has carried out numerous studies in this issue (Willems, 2001).

The Demirjian method has been widely used ever since and it is of special interest both for the orthodontists when planning therapeutical procedures of different kinds of malocclusions as well as in forensic examinations for the dental age determination of living persons and of human remains (Bagic et al., 2008). To improve this method, several authors developed alternative approaches based on the measurement of some significant tooth parameters, such as crown height, apex width and root length of the teeth observed in radiographs (Paevlinsky, 2005).

Willems et al. (2001), adapted a method for dental age estimation in a Belgian Caucasian population. It is a modification of Demirjian method (new tables for boys and girls with age scores directly expressed in years). The adapted method was validated and resulted in more accurate dental age estimations in this population.

Cameriere et al. (2006a), took a completely different approach and published a mathematical formula for calculating dental age on teeth for some European countries. The method is based upon measuring the completeness of apical development via a computer method and all studies to date show a very strong correlation to chronological age.

In the dental literature the existence of different patterns of dental maturation among different populations has been reported and hence, different standards were found in several countries (Rai, 2008). Since dental age assessment is considered important, the aim of the present study was to evaluate the suitability of using Willems method and Cameriere method standards in a sample of Egyptian children through analysis of panoramic X-ray on teeth. 


\section{SUBJECTS AND METHODS}

\section{Study design :}

It is a study of panoramic radiographs of patients treated at the Orthodontics Department (from Augest 2007 till Augest 2008), Faculty of Dentistry, Mansoura University.

\section{Samples :}

Panoramas taken from 286 Egyptian children (134 boys, 152 girls) aged between 5 and 16 years were analyzed (Cameriere et al., 2006a). Digital panoramic radiographs were assessed using Image Tool program for digitalized images (UTHSCSA, Texas, USA). The seven left permanent mandibular teeth were evaluated. The inclusion criteria were age between 5 and 16 years at the time of obtaining dental panorama, good quality radiographs, no agenesis or extractions in the left lower quadrant. Exclusion criteria were hypodontia or hyperdontia.

\section{Dental age methods:}

\section{1-Willems method:}

Each tooth on the left side of the mandible (except the third molar) is given a letter from $\mathrm{A}$ to $\mathrm{H}$ depending on its developmental criteria (Figure 1). Each letter corresponds to a score. Maturity scores were converted into fractions of dental age using published conversion tables then these were summed to obtain dental age. Different standards are used for boys and girls (Willems et al., 2001).

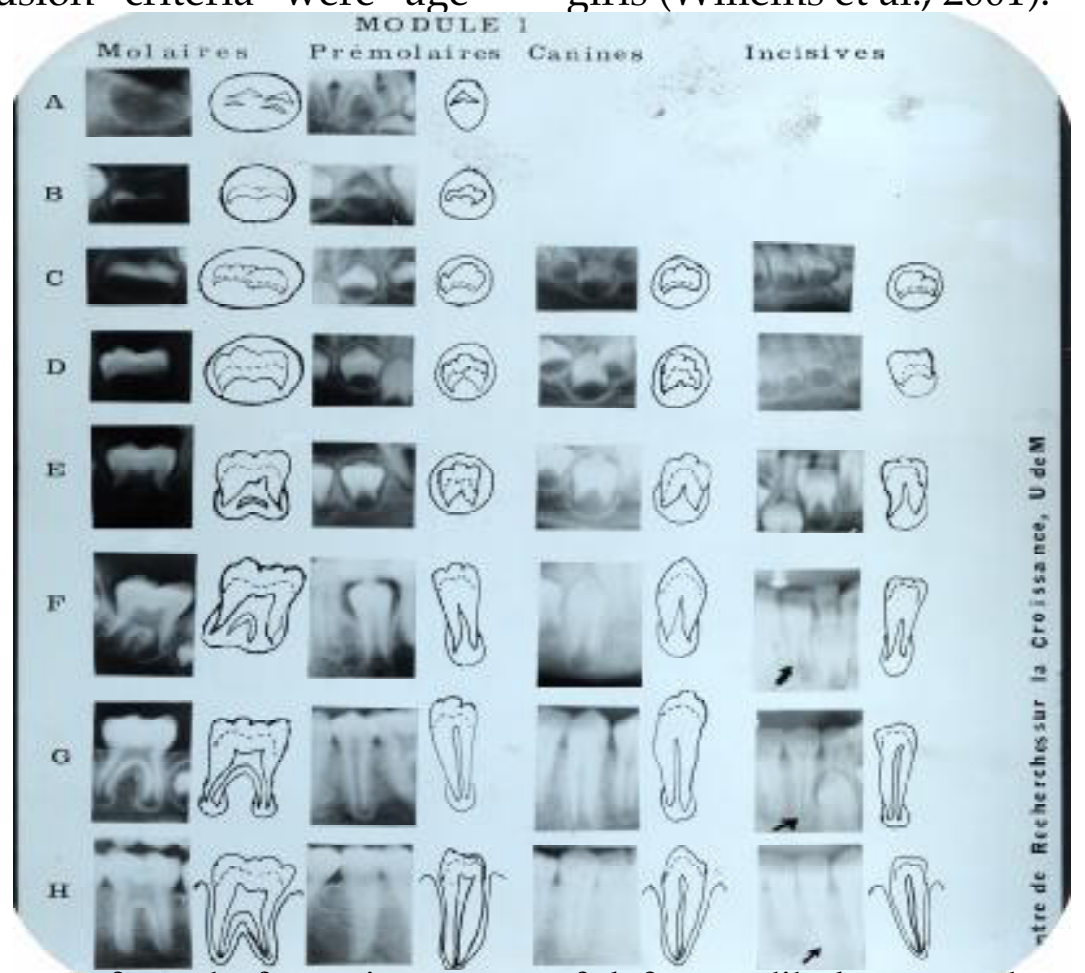

Fig. (1) : Assessment of tooth formation stage of left mandibular second molar, first molar, premolars, canine and incisors. The sum of scores fromWillem's table is the dental age. (Willems et al., 2001) 


\section{2- Cameriere method:}

The number of teeth with complete root development, apical ends of the roots completely closed (N0), was calculated. Furthermore, the teeth with incomplete root development and therefore with open apices, were considered. For teeth with one root, the distance $(\mathrm{Ai}, \mathrm{i}=1, \ldots, 5)$ between the inner sides of the open apex was measured. For teeth with two roots $(\mathrm{Ai}, \mathrm{i}=6,7)$, the sum of the distances between the inner sides of the two open apices was calculated.
To take into account the effect of possible differences in magnification and angulations among $\mathrm{X}$-rays, measurements were normalized by dividing it by the tooth length ( $\mathrm{Li}, \mathrm{i}=1, . ., 7)$. Finally, dental maturity was evaluated using the normalized measurements of the seven permanent mandibular teeth ( $\mathrm{xi}=\mathrm{Ai} / \mathrm{Li}, \mathrm{i}=1, \ldots, 7)$, the sum of the normalized open apices (s) and the number of teeth with complete root development (N0) (Figure 2). All measurements were carried out by the same observer.

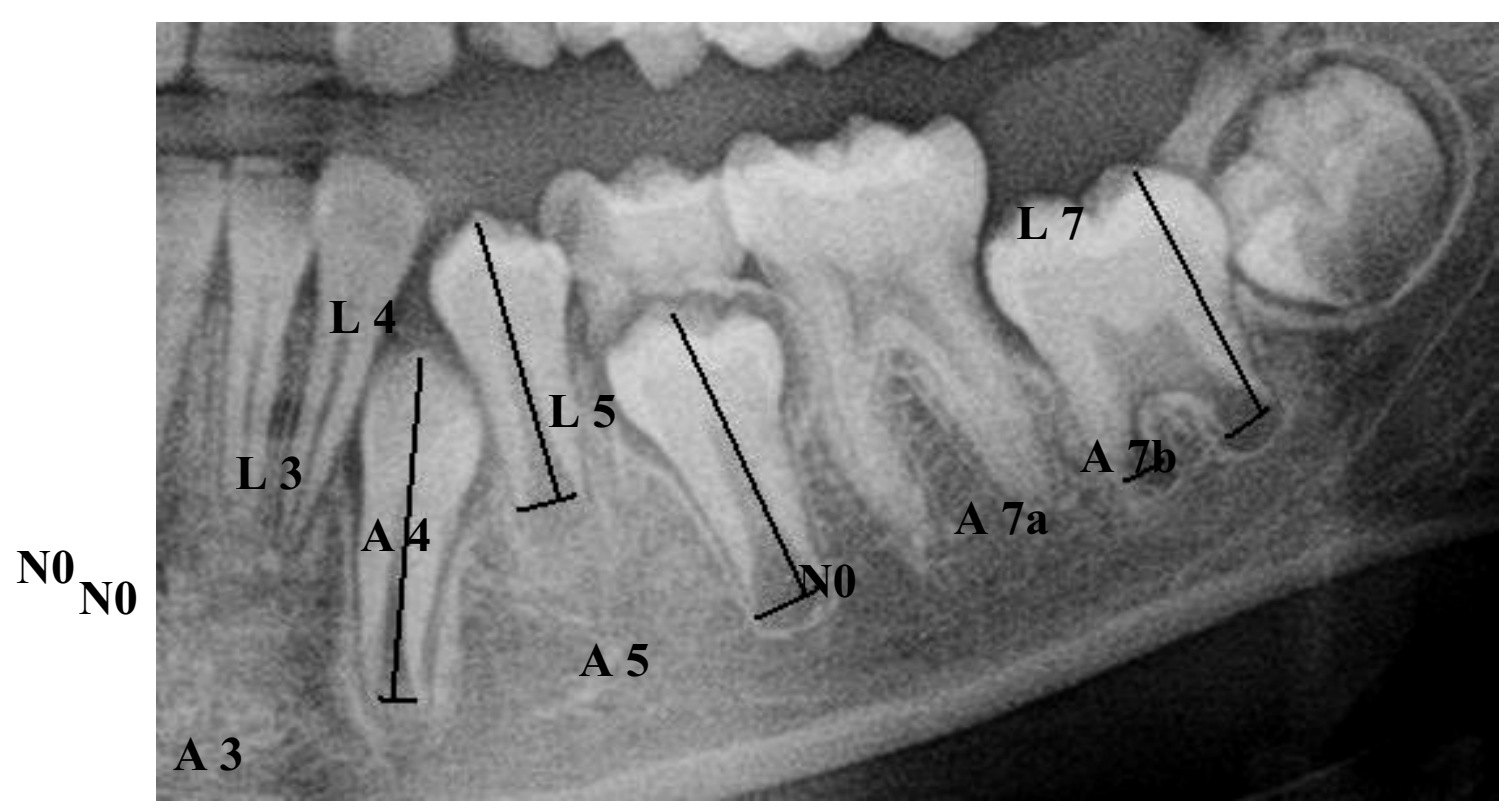

Fig. (2) : An example of tooth measurement. Ai, i=1, .,5 (teeth with one root), is the distance between the inner sides of the open apex; $\mathrm{Ai}, \mathrm{i}=6,7$ (teeth with two roots), is the sum of the distances between the inner sides of the two open apices; and $\mathrm{Li}, \mathrm{i}=1, \ldots, 7$, is the length of the seven teeth and NO is a tooth with closed root. 
All the morphological variables, $x i$, $\mathrm{i}=1, \ldots, 7, \mathrm{~s}, \mathrm{~N} 0$ and subjects' gender, were entered in an EXCEL file for use as predictive variables for age estimation in the subsequent statistical analysis. Chronological age, calculated by subtracting date of birth from the date of radiograph, was also recorded in the EXCEL file. Then the following linear regression formula was used:

$$
\text { Age }=8.971+0.375 \times \mathrm{g}+1.631 \times 5+
$$
0.674 N0 -1.034 s -0.176 s x N0

where $\mathrm{g}$ is a variable equal to 1 for boys and 0 for girls. Thus the equation points out to advanced dental maturity for girls at all ages (Cameriere et al., 2006a).

\section{Calculating accuracy :}

Dental age for each method was compared with chronological (real) age for each subject. The chronological age was subtracted from the dental age and positive result indicates an overestimation and negative figure an underestimation. Dental age estimation was carried out by two well trained observers. To test intra-observer reproducibility, a random sample of 50 panoramic radiographs were re-examined after an interval of 2 weeks.

Statistical analysis was performed with SPSS version 11.0 statistical program. Chronological age and both estimates of dental age were described by frequency distribution, means and standard deviation. Correlation between chronological age and dental age was examined by Pearson correlation coefficient. The percentage of error was calculated by dividing the subtract from chronological age and dental age over the chronological age. The percentage of accuracy (100 - percentage of error) was also evaluated.

Acknowledgment: The authors would like to acknowledge Prof. Dr Roberto Cameriere, Institute of Legal Medicine, University of Macerata, Italy and Simona Carmen for his great help.

\section{RESULTS}

Cross tabulation of age and sex groups is demonesterated in table (1). The results of this research showed that, age of the collected sample ranges from 5 years and 10 months $(5.83 \mathrm{y})$ to 15 years and 8 months (15.75 y), mean is $10.82 \pm 2.75$, while the mean age in girls was $11.04 \pm$ 2.69 y (range; 6.33 - 15.67) and in boys, it was $10.56 \pm 2.79$ y (range; 5.83 - 15.75) (Table 2).

Inter-observer reliability as assessed by reliability Alpha (Cronbach) is 0.985 . A significant positive correlation between ages estimated by both methods and chronological age is found for the total sample and in both sexes (Figures 3-10). 
Willems method showes an average over estimation of age by $0.15 \pm 0.62 \mathrm{y}$ for the total sample, $0.14 \pm 0.74 \mathrm{y}$ for girls and $0.29 \pm 0.48$ y for boys. While that by Cameriere method showes an average under estimation by $-0.29 \pm 1.04 \mathrm{y}$ for the total sample, $-0.26 \pm 1.21 \mathrm{y}$ for girls and $-0.49 \pm$ $1.03 \mathrm{y}$ for boys (Table 3).

Percentage of accuracy (100- percentage of error) is $98.62 \%$ for Willems method but Cameriere method is $98.02 \%$ accurate (data not shown).

\section{DISCUSSION}

Tooth formation has been more widely used than tooth eruption for assessing dental maturation because it is a continuous and progressive process that can be followed radio-graphically and most teeth can be evaluated at each examination (Rai, 2008). Several studies showed that morphological measurements can be reliably made in panoramic radiography, provided that some corrections are made to take into account the individual variability of tooth size and the differences in magnification of radiographs and angulation between $x$-ray beam and film (Cameriere et al., 2006a).

It has been reported that development of each individual can be affected by genetic, racial, nutritional, climate, hormonal and environmental factors (Kull- man et al., 1992). Hence, considering the regional difference in country region like Egypt, would be very significant. The aim of this study was to evaluate the accuracy of Willems and Cameriere methods in dental aging of a sample of Egyptian children through panoramic radiographs analysis.

The results obtained in our study on both boys and girls showed a high correlation between the real chronological age and the age estimated by both Willems and Cameriere methods.

Age estimation in the studied sample by Willems method yielded an average over estimation of age by $0.14 \mathrm{y}$ for girls and $0.29 \mathrm{y}$ for boys being better in girls. When Willems method was applied on Belgian Caucasian population, an over estimation by median: 0.1 for boys and median: 0.2 for girls was demonstrated (Willems et al., 2001). Other authors had a similar observation on Indian population (Rai and Anand, 2006). However, both studies showed better accuracy for boys than girls. Willems method also yielded over estimation of dental age in a Malay population (Mani et al., 2008). Although (Cameriere et al., 2007b), confirmed an over estimation of age by Willems method in boys, they observed an under estimation of age in girls. In Bangladeshi and British Caucasian population, Willems method under estimated age by 
an average $0.05 \mathrm{y}$ for boys and $0.2 \mathrm{y}$ for girls (Maber et al., 2006).

In the present study, age estimation by Cameriere method resulted in an average under estimation of age by $0.26 \mathrm{y}$ for girls and $0.49 \mathrm{y}$ for boys. Similar results were observed in European population (Cameriere et al., 2006b; Cameriere et al., 2007a; Cameriere et al., 2007b). In Indian population, Cameriere method yielded a mean over estimation by $0.05 \mathrm{y}$ for boys and $0.04 \mathrm{y}$ for girls (Rai, 2008). This controversy can be explained by difference in genetic factor, environmental factors, nutritional factors and geographical factors (Rai and Anand, 2008).

Comparing the percentage of accuracy of both methods, Willems method was more accurate than Cameriere method. This confirms previous studies on Indian population (Rai and Anand, 2006). On Romanian children, Carmen (2008), compared the two methods. She concluded that both methods can be applied but Cameriere method was less accurate in older age group (11- 15 y) and in boys.
However, it is contradictory to that of Cameriere et al., (2007b), who found that Cameriere method was more accurate than Willems method in Europian population.

It is important to remember that the difference in chronological age and obtained dental ages (whatever the method used), can be attributed to numerous factors, such as the accuracy of the method's execution, the examiner's subjectivity, sample size, sample structure (age, sex, ethnicity, nationality and social status) and statistic approach to the obtained results (Bagic et al., 2008).

Based on the results of this research, it can be concluded that - both Willems and Cameriere methods are suitable for dental age estimation in Egyptian children, however, Willems method was slightly more accurate when applied on this sample of Egyptian population. Therefore, both methods can be recommended for practical application in clinical dentistry and forensic procedures on the Egyptian population. 
El-Bakary et al ...

Table (1) : Cross tabulation of age and sex groups.

\begin{tabular}{|c|c|c|c|}
\hline \multirow{2}{*}{ Age groups } & \multicolumn{2}{|c|}{ Sex } & \multirow{2}{*}{ Total } \\
\cline { 2 - 4 } & Females & Males & $6(2.1 \%)$ \\
\hline $\mathbf{5 - 6} \mathbf{y}$ & $0(0 \%)$ & $6(4.5 \%)$ & $25(8.7 \%)$ \\
\hline $\mathbf{6 - 7} \mathbf{y}$ & $9(5.9 \%)$ & $16(11.9 \%)$ & $20(7 \%)$ \\
\hline $\mathbf{7 - 8} \mathbf{y}$ & $7(4.6 \%)$ & $13(9.7 \%)$ & $37(12.9 \%)$ \\
\hline $\mathbf{8 - 9} \mathbf{y}$ & $29(19.1 \%)$ & $8(6 \%)$ & $20(7 \%)$ \\
\hline $\mathbf{9 - 1 0} \mathbf{y}$ & $16(10.5 \%)$ & $4(3 \%)$ & $50(17.5 \%)$ \\
\hline $\mathbf{1 0 - 1 1} \mathbf{y}$ & $26(17.1 \%)$ & $24(17.9 \%)$ & $14(4.9 \%)$ \\
\hline $\mathbf{1 1 - 1 2} \mathbf{y}$ & $8(5.3 \%)$ & $6(4.5 \%)$ & $27(9.4 \%)$ \\
\hline $\mathbf{1 2 - 1 3} \mathbf{y}$ & $3(2 \%)$ & $24(17.9 \%)$ & $48(16.8 \%)$ \\
\hline $\mathbf{1 3 - 1 4} \mathbf{y}$ & $23(15.1 \%)$ & $25(18.7 \%)$ & $17(5.8 \%)$ \\
\hline $\mathbf{1 4 - 1 5} \mathbf{y}$ & $17(11.2 \%)$ & $0(0 \%)$ & $22(7.7 \%)$ \\
\hline $\mathbf{1 5 - 1 6} \mathbf{y}$ & $14(9.2 \%)$ & $8(6 \%)$ & $286(100 \%)$ \\
\hline Total & $152(100 \%)$ & $134(100 \%)$ & \\
\hline
\end{tabular}

Table (2): Mean and standard deviation of chronological age and ages estimated by both methods (in years).

\begin{tabular}{|c|c|c|c|c|}
\hline \multicolumn{2}{|c|}{} & $\begin{array}{c}\text { Total } \\
\text { (boys and girls) }\end{array}$ & Girls & Boys \\
\hline $\begin{array}{c}\text { Chronological } \\
\text { Age }\end{array}$ & $\begin{array}{c}\text { Range } \\
\text { Mean } \pm \text { SD }\end{array}$ & $5.83-15.75$ & $6.33-15.67$ & $5.83-15.75$ \\
$10.82 \pm 2.75$ & $11.04 \pm 2.69$ & $10.56 \pm 2.79$ \\
\hline $\begin{array}{c}\text { Dental age } \\
\text { (Willems method) }\end{array}$ & Range & $6.41-16.03$ & $6.94-15.79$ & $6.41-16.03$ \\
& mean \pm SD & $10.97 \pm 2.65$ & $11.1 \pm 2.56$ & $10.83 \pm 2.75$ \\
\hline Dental age & Range & $6.64-14.06$ & $6.68-14.06$ & $6.64-14.06$ \\
(Cameriere method) & mean \pm SD & $10.39 \pm 2.14$ & $10.39 \pm 2.05$ & $10.39 \pm 2.24$ \\
& & & & \\
\hline
\end{tabular}

Table (3): The estimated error (in years) by both methods

\begin{tabular}{|c|c|c|c|c|}
\hline \multicolumn{2}{|c|}{} & $\begin{array}{c}\text { Total } \\
\text { (boys and girls) }\end{array}$ & Girls & Boys \\
\hline Willems method & (mean \pm SD) & $0.15 \pm 0.62$ & $0.14 \pm 0.74$ & $0.29 \pm 0.48$ \\
\hline Cameriere method & (mean \pm SD) & $-0.29 \pm 1.04$ & $-0.26 \pm 1.21$ & $-0.49 \pm 1.03$ \\
\hline
\end{tabular}

Mansoura J. Forensic Med. Clin. Toxicol.

Vol.XVII, No.1, Jan. 2009 


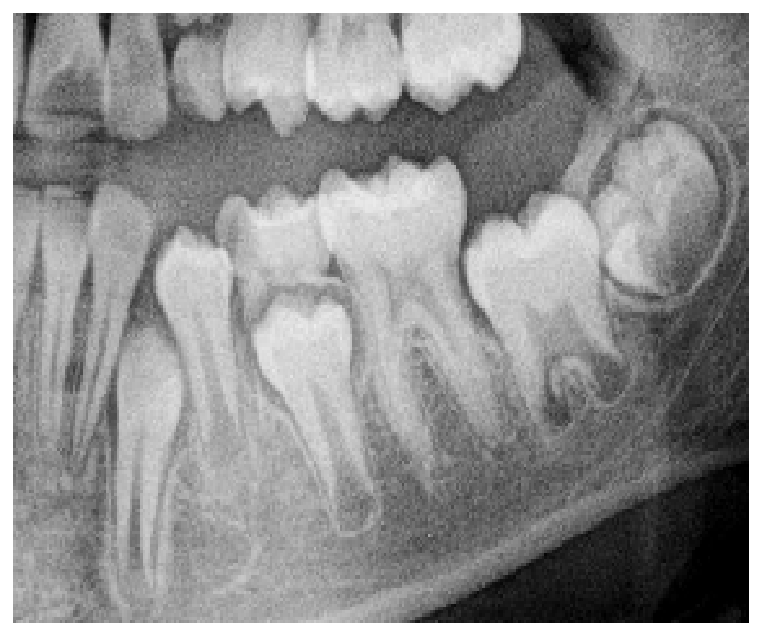

Fig. (3) : An example of panorama of a male. His chronological age was $10.75 \mathrm{y}$. Age estimation by Willems method was $10.88 \mathrm{y}$ and that by Cameriere method was $10.61 \mathrm{y}$.

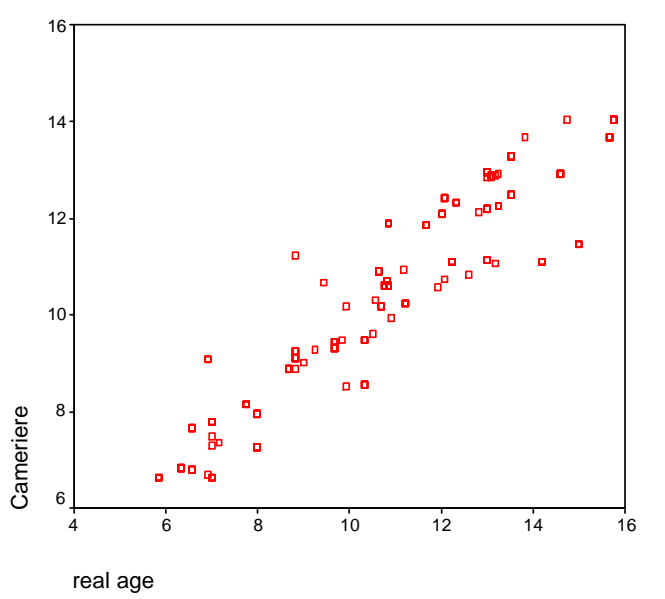

Fig. (5) : Showing correlation between ages estimated by Cameriere method and chronological age in total sample $(\mathrm{p}=0.000)$.

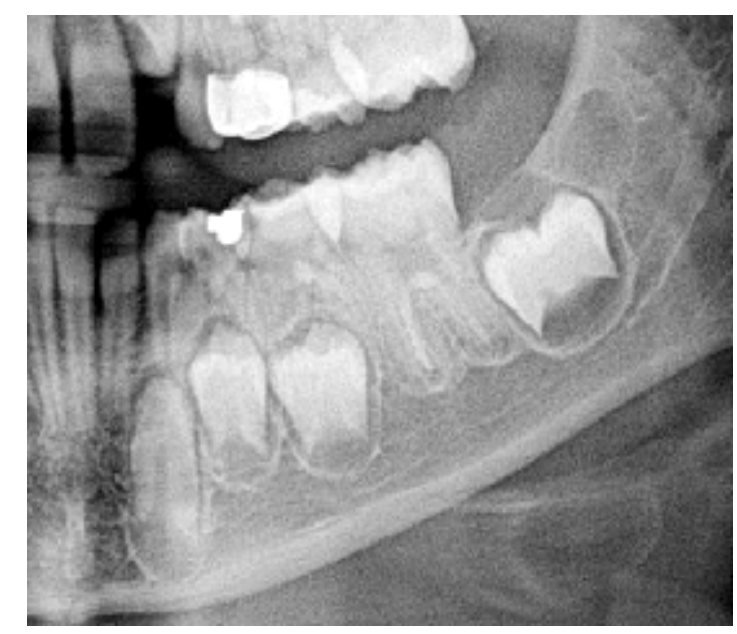

Fig. (4) : An example of panorama of a female. Her chronological age was 8 y. Age estimation by Willems method was $7.92 \mathrm{y}$ and that by Cameriere method was $7.97 \mathrm{y}$.

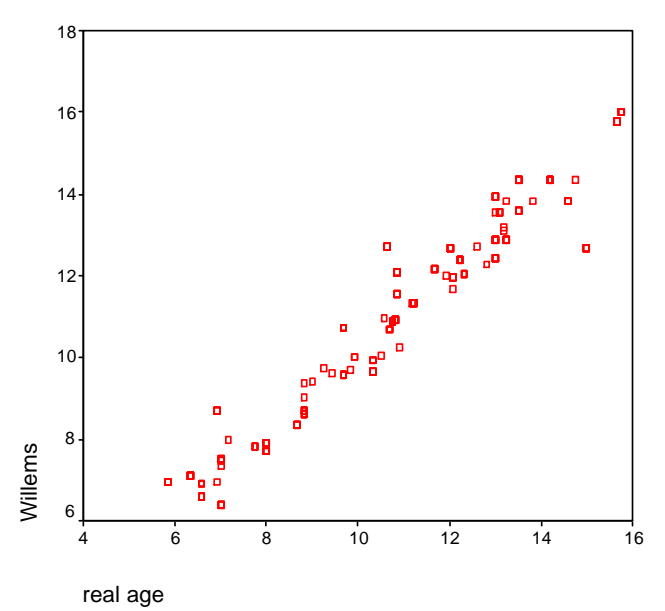

Fig. (6) : Showing correlation between ages estimated by Willems method and chronological age in total sample $(\mathrm{p}=0.000)$. 


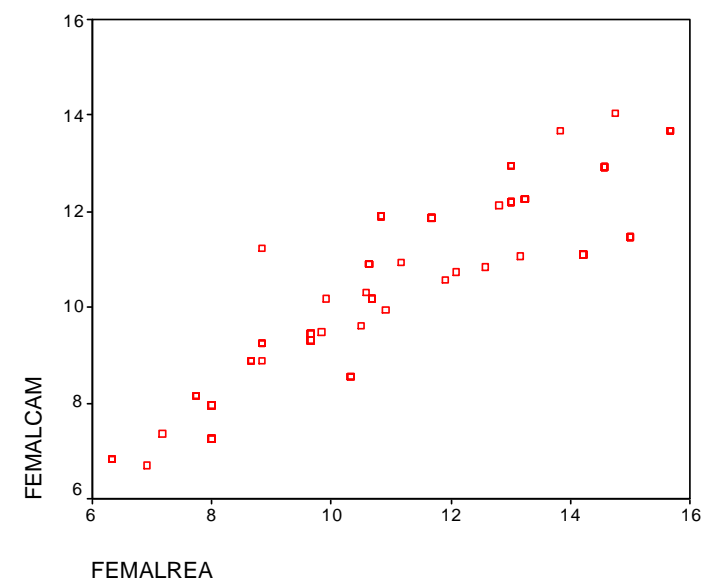

Fig. (7) : Showing correlation between ages estimated by Cameriere method and chronological age in girls $(\mathrm{p}=0.000)$.

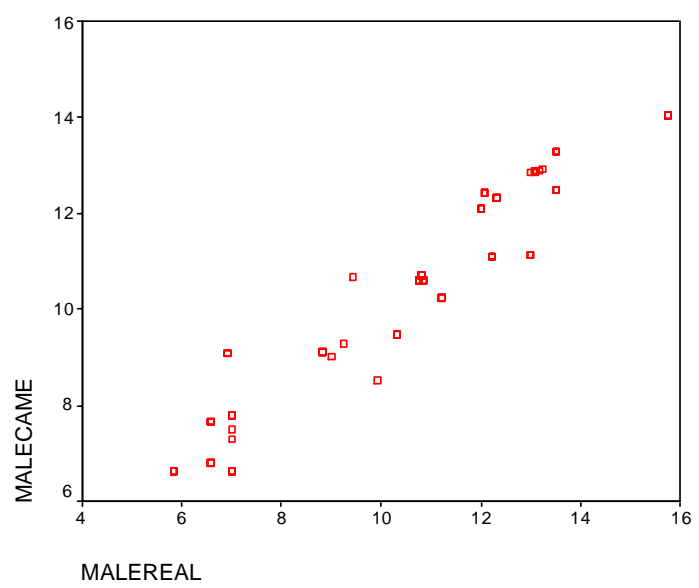

Fig. (9) : Showing correlation between ages estimated by Cameriere method and chronological age in boys $(\mathrm{p}=0.000)$.

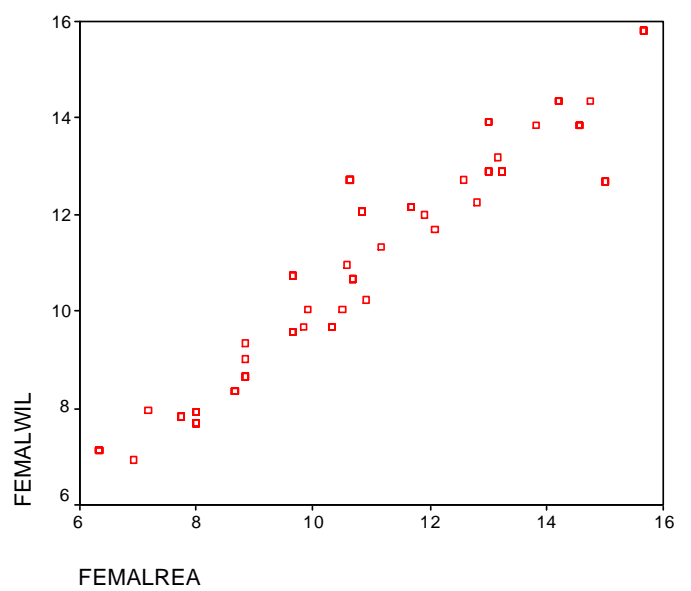

Fig. (8) : Showing correlation between ages estimated by Willems method and chronological age in girls $(\mathrm{p}=0.000)$.

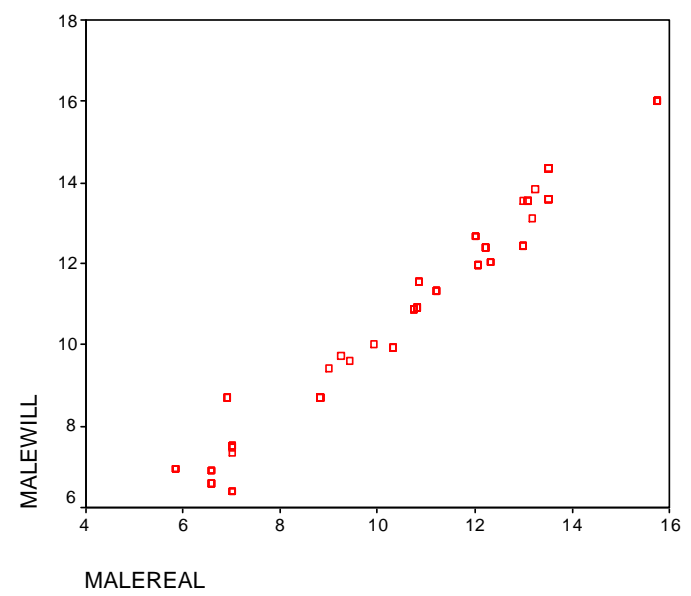

Fig. (10) : Showing correlation between ages estimated by Willems method and chronological age in boys $(\mathrm{p}=0.000)$. 


\section{REFERENCES}

Al-Emran, S. (2008): “Dental age assessment of 8.5 to 17 year-old Saudi children using demirjian's method". Contemporary Dental Practice, (9)3: 64-71.

Bagic, I. C.; Sever, N.; Brkic, H. and Kern, J. (2008) : “Dental age estimation in children using orthopantomograms". Acta Stomatol. Croat., 42(1):11-18.

Cameriere, R.; Angelis, D. D.; Ferrante, L.; Scarpino, F. and Cingolani, M. (2007a): "Age estimation in children by measurement of open apices in teeth: a European formula". Int. J. Legal Med., 121 (6) : 449453.

Cameriere, R. and Ferrante, L. (2008) : "Age estimation in children by measurement of carpals and epiphyses of radius and ulna and open apices in teeth: a pilot study". Forensic Sci. Int., (174) 1: 5962.

Cameriere, R.; Ferrante, L. and Cingolani, M. (2006a) : "Age estimation in children by measurement of open apices in teeth". Int. J. Legal Med., 120: 49-52.

Cameriere, R.; Ferrante, L.; Liversidge, H. M.; Prieto, J. L. and Brkic, H. (2007b) : "Accuracy of age estimation in children using radiograph of developing teeth". Forensic Sci. Int., 176(2-3):173-177.
Cameriere, R., Ferrante, L.; Scarpino, F.; Ermenc, B. and Zeqiri, B. (2006b) : "Dental age estimation of growing children: comparison among various European countries". Acta Stomatol. Croat., 40 (2):256-262.

Carmen, S. (2008) : The applicapility of two dental age estimation techniques to Romanian children. Procceding from the $3^{\text {rd }}$ Egyptian International Conference of Medical and Forensic Sciences (Absrtact).

Demirjian, A.; Goldstein, $H$. and Tanner, J. M. (1973) : "A new system of dental age assessment". Hum. Biol., 45: 221-227.

Kullman, L.; Johanson, G. and Akesson, L. (1992) : "Root development of the lower third molar and its relation to chronological age". Swed. Dent. J., 16: 161167.

Maber, M.; Liversidge, H. M. and Hector, M. P. (2006) : "Accuracy of age estimation of radiographic methods using developing teeth". Forensic Sci. Int., 15 (159): 68-73.

Mani, S. A.; Naing, L.; John, J. and Amsudin, A. R. (2008) : "Comparison of two methods of dental age estimation in 7-15-year-old Malays". Int. J. Paediatric Dentistry, 18 (5) : 380-388. 
Paevlinsky, E.; Pfeiffer, H. and Brinkmann, B. (2005) : "Quantification of secondary dentine formation from orthopantomograms- a contribution to forensic age estimation methods in adults". Int. J. Legal Med., 119:27-30.

Rai, B. (2008) : "An accuracy of four methods of age estimation from panoramic radiographs". Inter. J. Dental Anthropol., 13: 7-10.

Rai, B. and Anand, S. C. (2006) : “Tooth developments: an accuracy of age estimation of radiographic methods". World Medical Sciences, 1 (2) : 130-132.

Rai, B. and Anand, S. C. (2008) : "Age estimation in children from dental radiograph : a regression equation".
The Internet Journal of Biological Anthropology, (1) 2 : [serial on the internet]. Available from: http://www. ISPUB.com.

Tunc, E. S. and Koyuturk, A. E. (2008): "Dental age assessment using Demirjian's method on northern Turkish children". Forensic Sci. Int., 25;175(1):23-26.

Willems, G. (2001) : "A review of the most commonly used dental age estimation techniques". J. Forensic Odontostomatol., 19: 9-17.

Willems, G.; Van Olmen, A.; Spiessens, B. and Carels, C. (2001) : “Dental age estimation in Belgian children: Demirjian's technique revisited". J. Forensic Sci., 46 (4):893-895. 


\title{
مقارنة بين طريقتين لقياس العمر السنى للأطفال الهصريين
}

\author{
المشتركون فى البحث

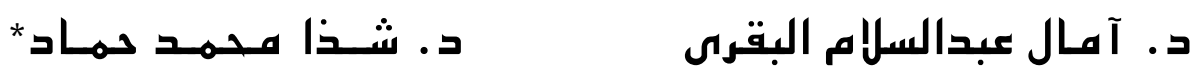

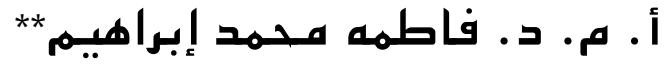

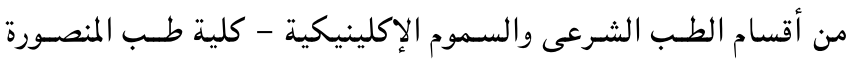

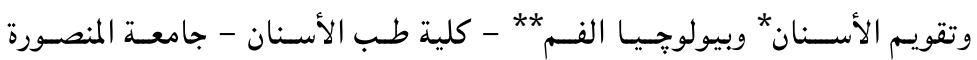

هناك حاجة مستمرة لقياس سن الأطفال حيث أنه من القياسات المهمة والمفيدة فى مجالات مختلفة وخصوصاً فى الطب الشرعى وتقويم

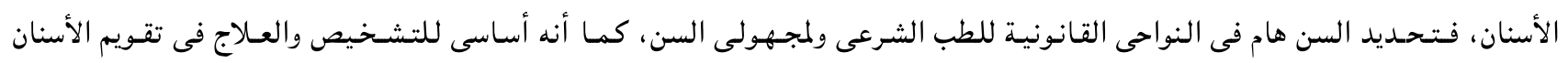

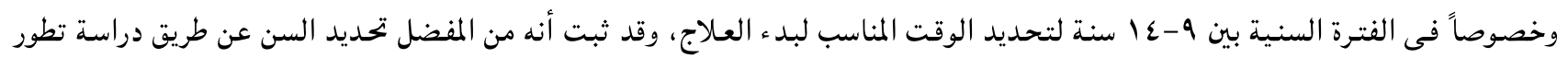

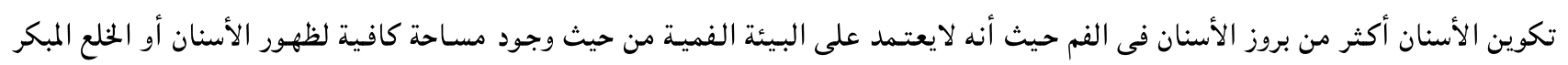

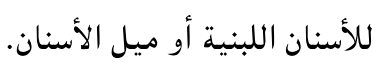

ومن الطرق المستخدمة طريقة ويلمز والتى تعتبر طريقة معدلة من طريقة ديرجيان والتى أستخدمت فى بلغاريا للقوقازيين عن طريق استخدام

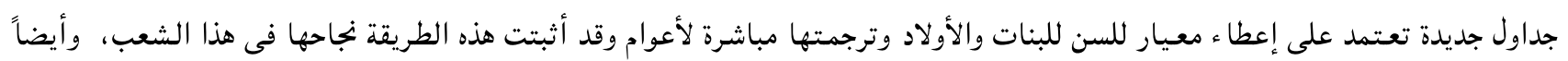
طريقة كاميرير والتى تعتمد على التعويض فى معادلة حسابية عن طريق قياس جذور الأسنان المكتملة والغير مكتملة والتى أثبتت أيضاً فاعلية

$$
\text { فى الشعوب الأوروبية. }
$$

ونظراً لاختلاف المعايير تبعاً لاختلاف الشعوب، فقد كان الهدف من هذه الدراسة المقارنة بين الطريقتين فى عينة من الأطفال المصريين لتحديد

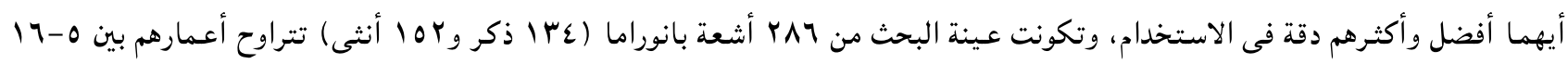

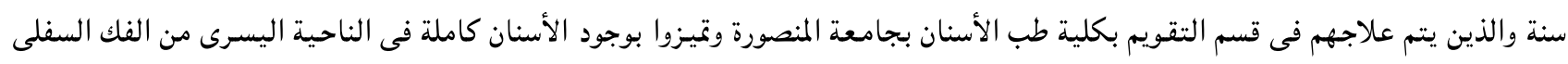

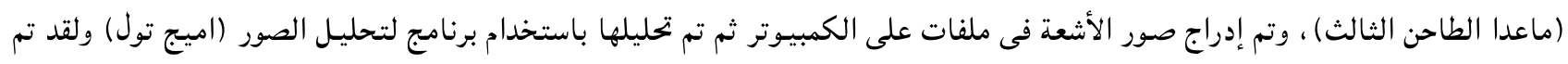

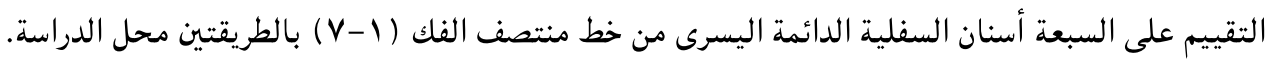

وقد أظهرت النتائج وجود علاقة ارتباط طردية ذات دلالة إحصائية بين العمر الحقيقى والعمر التقديرى باستخدام الطريقتين ولقد تبين من

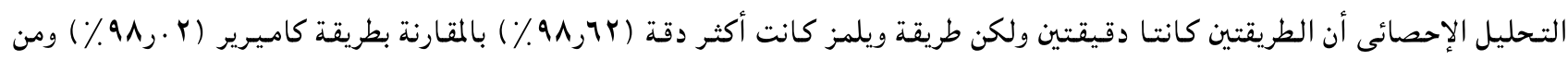
الملاحظ أن الطريقتين كانتا أكثر دقة فى البنات عن البنين كما توصلت الدراسة لإمكانية استخدام الطريقتين معاً على الأطفال المصريين. 